QUALITY

Volume 5, Nomor 2, 2017: 333-353

\title{
STRATEGI MANAJEMEN KUALITAS DALAM MENINGKATKAN \\ MUTU PENDIDIKAN ISLAM \\ DI MTS NEGERI 2 MODEL PALEMBANG
}

\author{
Hilyah Alan Finandar \\ MTs Negeri 2 Model Palembang
}

\begin{abstract}
Abstrak
Kualitas pendidikan sebagai pilar pengembangan sumber daya manusia, erat hubungannya dengan manajemen pada lembaga pendidikan. Pendidikan yang berkualitas akan muncul apabila sekolah berkualitas, yang tidak terlepas dari pengelolaan secara benar. Kualitas pendidikan tidak terlepas atas inputs, proses, outputs maupun outcomes. Oleh sebab itu, pendidikan harus terus menerus di tingkatkan kualitasnya melalui suatu sistem manajemen yang dapat di pertanggung jawabkan kepada para stakeholder agar mampu mempersiapkan generasi penerus yang memiliki keunggulan kompetitif dalam menjawab dan memecahkan tantangan masa depan bangsa di era global.
\end{abstract}

Kata Kunci: Strategi, TQM, Pendidikan Islam.

\begin{abstract}
The quality of education as a pillar of human resource development, closely related to management at educational institutions. Quality education will arise if quality schools, which can not be separated from the management properly. The quality of education is not independent of inputs, processes, outputs or outcomes. Therefore, education must be continuously upgraded through a management system that can be accountable to stakeholders in order to be able to prepare future generations who have a competitive advantage in answering and solving the future challenges of the nation in the global era. The reason for choosing in MTs Negeri 2 Palembang because in terms of acceptance of MTs Negeri 2 Palembang receive inputs with the selection of both written tests and test kaji. In the process of education continues to increase the potential of existing teachers proven teachers who have S2 as much as 6 people. Outputs issued can penetrate state high school and Madrasah Aliyah Negeri and students who excel, therefore MTs Negeri 2 Palembang can be used as a model.
\end{abstract}

Keywords: Strategy, Total Quality Management, Islamic Education.

\section{A. Pendahuluan}

Fenomena madrasah yang masih dianggap sebagai lembaga pendidikan kedua, yang seringkali keberadaannya dianggap hanya sebagai sekolah cadangan. Apalagi hampir semua madrasah dalam upaya pengembangannya, masih tergolong miskin sumber daya, ditambah pula dengan sistem pengelolaan yang 
kurang profesional, membuat madarasah kurang bermutu dan outputsnya tidak dapat bersaing dengan alumni dari sekolah umum lainnya. Departemen Agama melalui proyek pengembangan madrasah menyatakan juga bahwa ada beberapa kelemahan yang hingga kini masih dialami oleh madrasah antara lain rendahnya kemampuan manajerial pengelolaan madrasah, rendahnya kemampuan ekonomi sebagian besar orang tua siswa, kurangnya guru berkualitas (hanya sekitar 20\% saja dari total guru madrasah yang layak; $20 \%$ mismatch, dan $60 \%$ belum atau tidak layak), kurangnya fasilitas pendidikan dan dukungan pembiayaan (Azra, 2000: 28). Berbagai kelemahan ini berdampak buruk pada proses belajar mengajar yang dilaksanakan. Kelemahan-kelemahan tersebut menjadi salah satu penyebab bagi tidak terwujudnya proses kegiatan belajar mengajar yang tidak berkualitas ini yang berpengaruh terhadap mutu lulusan (kualitas produk).

Pada era otonomisasi pendidikan saat ini peluang madrasah untuk melakukan inovasi dan improvisasi dalam pengelolaan madrasah terbuka luas. Madrasah perlu melakukan penyesuaian segala aspek yang melekat pada dirinya, untuk mencapai upaya peningkatan kualitas madrasah. Peningkatan kualitas tidaklah dapat dilakukan secara terpisah-pisah atau bagian perbagian, namun setiap komponen dan sistem saling terpadu dan bekerjasama di dalam usaha perbaikan kualitas madrasah. Dalam konteks pendidikan, pengertian mutu mencakup inputs, proses dan outputs pendidikan (Depdiknas, 2001: 24-25).

Inputs pendidikan adalah segala sesuatu yang harus tersedia karena dibutuhkan untuk berlangsungnya proses. Sesuatu yang diharapkan berupa sumber daya dan perangkat lunak serta harapan-harapan sebagai pemandu bagi berlangsungnya proses. Inputs sumber daya meliputi sumber daya manusia (kepala sekolah, guru, konselor, karyawan, dan peserta didik) di MTs Negeri 2 Palembang telah memiliki sumber daya manusia yang memadai, seperti guru yang sudah menempuh pendidikan S2 sebanyak 6 orang dan peserta didik yang menempuh jalur seleksi masuk yaitu tes pelajaran umum, agama dan mengaji.Dan sumber daya selebihnya adalah peralatan, perlengkapan dan lain-lain. 


\section{B. Pembahasan}

\section{Konsep Strategi Manajemen Kualitas}

Dalam konsep TQM kualitas ataupun mutu merupakan suatu tujuan TQM yang ingin dicapai untuk memuaskan pelanggan, dalam hal ini pengguna pendidikan. Kata kualitas memiliki banyak definisi yang berbeda, dan bervariasi. Menurut Vicent Gasperz definisi dari kualitas itu sendiri dibagi menjadi dua definisi (definisi konvensional dan definisi strategik) (Gasperz, 2001 : 4).Definisi konvensional memandang kualitas dari segi karakteristik langsung dari suatu produk seperti: performansi (performance), keandalan (reliability), mudah dalam penggunaan (ease of use), estetika (esthetics), dan sebagainya. Sedangkan kualitas yang berdasarkan definisi strategik memandang kualitas sebagai segala sesuatu yang mampu memenuhi keinginan atau kebutuhan pelanggan (meeting the needs of customers).

Deming menyatakan bahwa mutu merupakan suatu tingkat yang dapat diprediksi dari keseragaman dan ketergantungan pada biaya yang rendah dan sesuai dengan pasar; menurut Crosby dikatakan bermutu jika suatu produk itu sesuai dengan persyaratan (comformance to $=$ requirements); sedangkan menurut Juran suatu barang atau jasa dikatakan berkualitas jika memiliki kemampuan untuk digunakan (fitness for use) (Tunggal, 1998 : 80). Organisasi yang menerapkan TQM memandang kualitas dari sudut pandang pelanggan. Karena pelangganlah sebagai pihak yang menilai kualitas dan tanpa adanya pelanggan maka suatu organisasi tidak akan ada artinya. Dalam pengelolaan pendidikan, pelanggan dapat dikategorikan menjadi pelanggan internal dan eksternal. Menurut pendapat Sallis guru, dosen, dan anggota staf lainnya dalam institusi pendidikan merupakan pelanggan internal, sedangkan pelanggan eksternal adalah peserta didik, orang tua, dan lainnya (Sagala, $2004: 44$ ).

Lembaga pendidikan bukanlah suatu tempat untuk memproduksi suatu produk, tetapi sebagai tempat pemberian jasa atau pelayanan (service). Pemahaman karakteristik kualitas jasa lebih sulit untuk didefinisikan dari pada 
kualitas produk fisik. Untuk itu kita perlu memahami beberapa perbedaan produksi jasa dan produksi barang (Nurkolis,2003 : 69-70)yaitu:

1. Jasa layanan biasanya terjadi kontak langsung antara penyedia jasa dengan pengguna akhir, maka kualitas jasa bergantung pada orang yang memberikan pelayanan dan orang yang menerima pelayanan.

2. Jasa harus diberikan secara tepat waktu karena pelayanan dikonsumsi secara langsung pada saat jasa itu diberikan. Kontrol kualitas jasa dilakukan sebelum dan selama jasa tersebut diberikan. Adanya kontak langsung tersebut memungkinkan adanya evaluasi feedback yang merupakan sarana utama untuk mengukur kepuasan pelanggan.

3. Jasa pelayanan tak dapat ditambal sulam atau diperbaiki. Oleh karena itu, penting sekali untuk ditetapkan standar pelayanan dari tahap awal. Selain itu, dalam memberikan pelayanan memungkinkan untuk terjadinya kesalahan manusia.

4. Jasa pelayanan berkaitan dengan masalah-masalah yang tidak kelihatan sehingga sulit sekali untuk menggambarkan seperti apa keinginan pelanggan. Dalam jasa pelayanan lebih banyak menyangkut proses dari pada hasil akhirnya.

5. Jasa pelayanan biasanya diberikan secara langsung kepada pelanggan oleh pegawai yunior, sedangkan pegawai senior berada jauh dari pelanggan. Oleh karena itu, pegawai yunior terutama yang berada di garda depan (front line) harus dimotivasi untuk selalu memberikan pelayanan terbaiknya.

6. Sangat sulit untuk mengukur keberhasilan output dan produktivitas jasa pelayanan. Satu-satunya indikator kinerja jasa pelayanan adalah kepuasan pelanggan. Dalam hal ini ukuran-ukuran yang tidak tampak merupakan faktor kesuksesan yang penting seperti perhatian, kesopanan, keramah tamahan, dan pemberian bantuan

Dengan demikian satu-satunya indikator kinerja jasa pelayanan adalah kepuasan pelanggan, kinerja kualitas pendidikan dapat diukur dari tingkat kepuasan pelanggan. Oleh karena itu diperlukan suatu perbaikan mutu secara terus menerus yang merupakan upaya untuk meningkatkan kinerja organisasi dalam rangka memenuhi kebutuhan, keinginan dan kepuasan pelanggan.

Istilah mutu merujuk pada pemenuhan harapan dan kebutuhan pemakai produk atau jasa tertentu, sehingga tidak harus selalu berarti memerlukan biaya mahal. Berdasarkan pendapat Zeithaml et.al yang dikutip oleh Sudarwan Danim mengemukakan kriteria mutu layanan, yaitu : 
a. Tangiables: Appearance of physical facilities, equipment, personnel, and communication materials.

b. Reliability: Ability to perform the promised service dependably and accurately.

c. Responsiveness: Willingness to help customers and provide prompt service.

d. Assurance: knowledge and courtesy of employess and their ability to convey trust and confidence.

e. Emphaty: Caring, individualized attention the firm provides it customers (Sudarwan Danim, 2002 : 121).

Berdasarkan pendapat Zeithaml et.al, maka dalam mengevaluasi mutu kinerja pengelolaan pendidikan, dapat kita lihat dari beberapa perspektif seperti yang dikemukakan di atas. Pertama, bukti langsung, yang meliputi fasilitas fisik, perlengkapan, kondisi ketenagaan, dan sarana komunikasi. Misalnya, fasilitas pembelajaran (gedung) (gedung yang ada sudah cukup untuk proses belajar mengajar), fasilitas laboratorium, perpustakaan, media pembelajaran, kantin, tempat parkir, sarana ibadah, fasilitas olahraga, dan dapat juga busana penampilan staf administrasi maupun staf pengajar.

Kedua, Keandalan atau reliabilitas, berupa kemampuan memberikan layanan secara cepat dan memuaskan. Misalnya, mata ajaran yang banar-benar sesuai dengan kebutuhan, jadwal pembelajaran, proses pembelajaran yang akurat, penilaian yang objektif, bimbingan dan penyuluhan, serta aktivitas lain yang semuanya untuk memperlancar proses pembelajaran peserta didik.

Ketiga, Daya tanggap atau keresponsifan, berupa keinginan para staf pengelola untuk membantu memberikan pelayanan kepada pengguna. Misalnya guru pembimbing mudah ditemui untuk konsultasi. Proses pembelajaran interaktif sehingga memungkinkan peserta didik lebih memperluas wawasan berfikir dan kreativitasnya, prosedur administrasi lembaga pendidikan menjadi lebih sederhana.

Keempat, Jaminan atau asuransi, mencakup kemampuan, sopan santun, dan sifat-sifat yang dapat dipercaya dari kalangan staf pengelola suatu lembaga organisasi. Misalnya, seluruh staf administrasi, staf pengajar, maupun pejabat 
struktural harus benar-benar kompeten dibidangnya sehingga reputasi lembaga pendidikan positif dimata masyarakat.

Kelima, Empati, berupa kemudahan dalam melakukan hubungan, komunikasi dengan baik, perhatian pribadi, dan memahami kebutuhan peserta didiknya. Misalnya, staf pengajar mengenal siswanya yang mengikuti proses pembelajaran, guru bisa benar-benar berperan sesuai fungsinya, perhatian yang tulus diberikan kepada para siswanya berupa kemudahan mendapatkan pelayanan, keramahan, komunikasi, serta kemampuan memahami kebutuhan siswanya.

Kualitas bukanlah atribut dari suatu produk atau jasa. Suatu produk atau jasa baru dapat dinilai kualitasnya apabila barang atau jasa tersebut telah sesuai dengan spesifikasi yang ditetapkan sebelumnya. Dalam dunia pendidikan kualitas lulusan baru dapat dinilai kualitasnya apabila mereka telah memiliki kemampuan sesuai dengan perencanaan dalam kurikulum yang ditetapkan madrasah/sekolah. Kualitas bukan merupakan titik akhir, melainkan sebagai sarana agar barang dan jasa selalu berada di atas standar.

Dalam konteks pendidikan, pengertian mutu mencakup inputs, proses dan outputspendidikan (Depdiknas, 2001: 24-25) ; Inputs pendidikan adalah segala sesuatu yang harus tersedia karena dibutuhkan untuk berlangsungnya proses. Sesuatu yang diharapkan berupa sumber daya dan perangkat lunak serta harapanharapan sebagai pemandu bagi berlangsungnya proses. Inputs sumber daya meliputi sumber daya manusia (kepala sekolah, guru, konselor, karyawan, dan peserta didik). Dan sumber daya selebihnya adalah peralatan, perlengkapan dan lain-lain. Inputs perangkat meliputi: struktur organisasi sekolah, peraturan perundang-undangan, deskripsi tugas, rencana, program dan lain-lain. Inputs harapan berupa visi, misi, tujuan, dan sasaran yang hendak dicapai oleh sekolah/ madrasah.

Proses pendidikan merupakan berubahnya sesuatu menjadi sesuatu yang lain. Sesuatu yang berpengaruh terhadap berlangsungnya proses disebut inputs, sedang sesuatu dari hasil proses disebut outputs. Dalam pendidikan tingkat 
sekolah, proses yang dimaksud adalah proses pengambilan keputusan, proses pengelolaan kelembagaan, proses pengelolaan program, proses belajar mengajar dan proses monitoring dan evaluasi. Proses ini harus dikelola oleh kepala madrasah dengan koordinasi, penyerasian dan keterpaduan dengan inputs madrasah secara harmonis, guna menciptakan situasi pembelajaran yang menyenangkan, mendorong, memotivasi dan mampu memberdayakan peserta didik. Dari hasil wawancara yang dilakukan penulis MTs Negeri 2 Palembang mengadakan seleksi masuk dengan tes berupa tes pelajaran umum dan agama ditambah dengan tes kemampuan membaca al-Qur'an.

Outputs pendidikan adalah kinerja sekolah. Kinerja sekolah adalah prestasi sekolah yang dihasilkan dari proses/ perilaku sekolah. Kinerja sekolah dapat diukur dari kualitas, efektifitas, produktifitas, efisiensi, inovasi, kualitas kehidupan kerja dan moral kerja. Hasil kinerja yang baik itu biasanya dapat dilihat dari hasil kemampuan tes akademik berupa nilai semesteran, UAN/UAS, SPMB atau prestasi dibidang lainnya seperti olahraga, kesenian, keterampilan dan lain sebagainya. Dari hasil wawancara dan observasi penulis melihat MTs Negeri 2 palembang banyak mendapatkan penghargaan dibidang olahraga, kesenian dan keterampilan.

Inputs, proses, dan outputs di atas merupakan satu kesatuan yang tidak dapat dipisahkan satu sama lain. Dengan tingkat kesiapan inputs yang tinggi maka proses dapat berjalan dengan baik. Dan apabila proses berjalan dengan baik, maka outputs juga dapat berkualitas dan memenuhi harapan pelanggan, baik pelanggan internal maupun eksternal. Dengan demikian outcomes yang didapatkan sesuai yang diharapkan stakeholder.

\section{Kepemimpinan Kualitas dalam TQM}

Kepemimpinan yang efektif menurut konsep manajemen kualitas adalah kepemimpinan yang sensitif atau peka terhadap perubahan dan melakukan pekerjaannya secara terfokus (Gasperz: 199). Memimpin berarti menentukan halhal yang tepat untuk dikerjakan, menciptakan dinamika organisasi yang 
dikehendaki agar semua orang memberikan komitmen, bekerja dengan semangat dan antusias untuk mewujudkan hal-hal yang telah ditetapkan. Memimpin berarti juga dapat mengkomunikasikan visi dan prinsip organisasi kepada seluruh karyawan. Kegiatan memimpin termasuk menciptakan budaya atau kultur positif dan iklim yang harmonis dalam lingkungan organisasi, serta menciptakan tanggung jawab dan pemberian wewenang dalam pencapaian tujuan bersama (empowerment).

Kepemimpinan merupakan kemampuan untuk membangkitkan semangat orang lain agar bersedia dan memiliki tanggung jawab total terhadap usaha mencapai atau melampaui suatu tujuan (Nasution, t.th: 212). Kepemimpinan adalah unsur penting dalam TQM. Tanpa kepemimpinan, pada semua level institusi, proses peningkatan tidak dapat dilakukan dan diwujudkan. Komitmen terhadap mutu harus menjadi peran utama bagi seorang pemimpin, karena TQM adalah proses atas ke bawah (Top-down) (Sallis, t.th: 66).

Deming, Juran, dan Crosby sebagai guru dalam manajemen kualitas telah mengidentifikasikan bahwa proses perbaikan kualitas memerlukan keseimbangan antara perbaikan proses dan peningkatan sumber daya manusia yang dikendalikan oleh kepemimpinan kualitas, seperti pada gambar berikut ini.

\section{Gambar I}

Model Dasar Perbaikan Kualitas yang Diturunkan dari Kepemimpinan Kualitas 


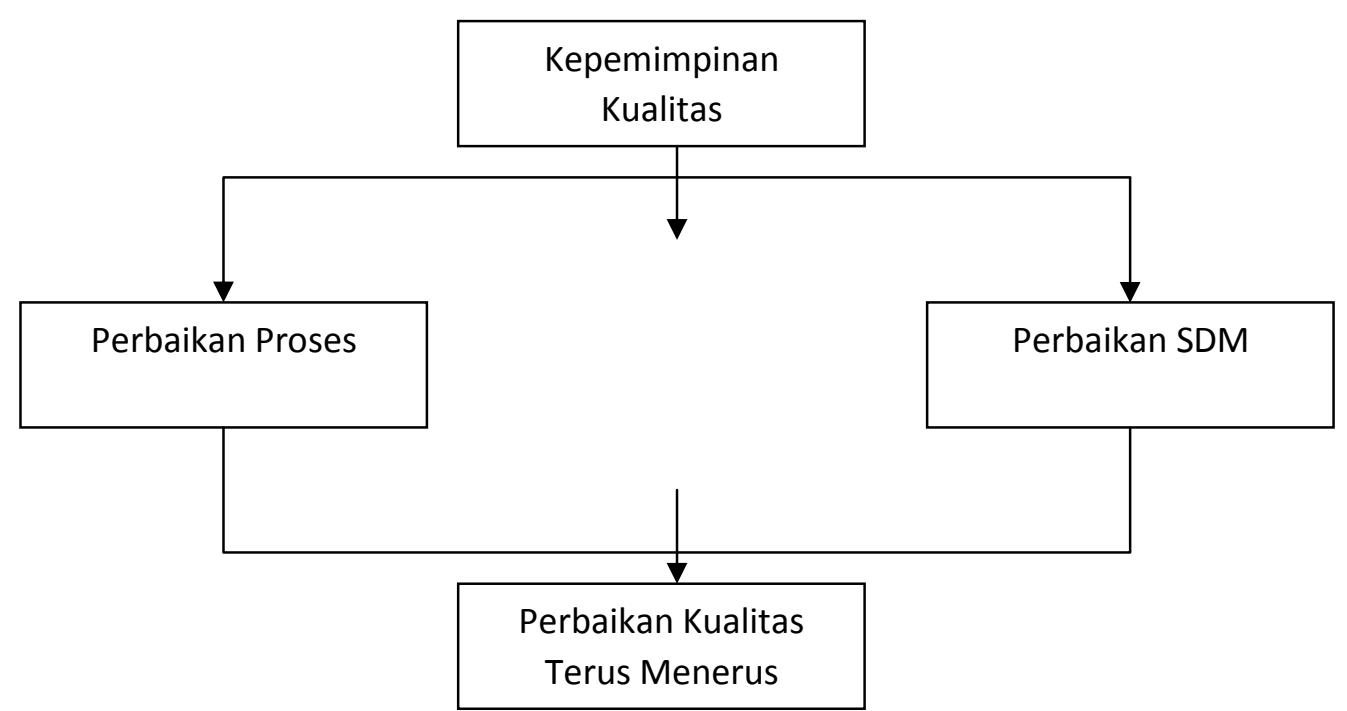

Sumber: Vincent Gaspersz, Total Quality Management, Jakarta: Gramedia Pustaka Utama, 2001.

Kepemimpinan kualitas pada dasarnya merupakan suatu proses pengaruh untuk perbaikan kualitas, dimana pemimpin mencoba mempengaruhi bawahan untuk melakukan apa yang dipandang penting oleh si pemimpin. Dalam manajemen kualitas, pemimpin secara simultan menetapkan arah dan tujuan kualitas sekolah serta memotivasi seluruh staf sekolah untuk maju secara bersama menuju perbaikan kualitas terus menerus. Pemimpin yang ada di MTs Negeri 2 Palembang menurut hasil pengamatan dan wawancara penulis mampu mempengaruhi dan mengarahkan bawahan dengan baik.Dalam manajemen kualitas dikenal salah satu pendekatan terbaru dalam kepemimpinan kualitas, yaitu kepemimpinan transformasional (transformational leadership). Pemimpin transformasional dapat memberikan pengaruh kuat pada rencana strategis kualitas yang menerapkan arah dari tujuan perbaikan terus menerus.

Pemimpin transformasional adalah pemimpin yang memiliki wawasan jauh ke depan dan berupaya memperbaiki dan mengembangkan organisasi bukan untuk saat ini tapi di masa datang (Komariah \& Triatna, 2005: 78). Kepemimpinan transformasional dapat juga diartikan sebagai kemampuan seseorang pemimpin bekerja dengan dan atau melalui orang lain untuk mentransformasikan secara optimal sumber daya organisasi dalam rangka mencapai tujuan yang bermakna 
sesuai dengan target capaian yang telah ditetapkan (Danim, 2006: 219). Sumber daya yang dimaksud dapat berupa SDM, fasilitas, dana, dan faktor-faktor eksternal keorganisasian. Di organisasi sekolah, SDM dimaksud dapat berupa pimpinan, staf, bawahan, tenaga ahli, guru, dosen, peneliti, dan lain-lain.

Kepemimpinan transformasional dicirikan dengan adanya proses untuk membangun komitmen bersama terhadap sasaran organisasi dan memberikan kepercayaan kepada para pengikut untuk mencapai sasaran. Dalam kepemimpinan transformasional ini, pemimpin harus mampu mentransformasi dan memotivasi para pengikutnya dengan cara: (1) membuat mereka lebih sadar mengenai pentingnya suatu pekerjaan, (2) mendorong mereka untuk lebih mementingkan organisasi daripada kepentingan diri sendiri, dan (3) mengaktifkan kebutuhankebutuhan pengikut pada taraf yang lebih tinggi (seperti halnya aktualisasi diri) (Nurholis, t.th.: 172). Ada beberapa karakteristik penting dari pemimpin transformasional yang diperlukan dalam dinamika perbaikan manajemen kualitas adalah sebagai berikut(Nasution : 204-205):

1. Memiliki visi yang kuat. Pemimpin transformasional memiliki visi yang kuat tentang bagaimana suatu lembaga pendidikan harus berjalan dengan baik serta mampu mentransformasikan visi ini kebawahan atau pengikut-pengikutnya. Dengan demikian visi dari pemimpin transformasional akan menjadi visi bersama dari seluruh anggota organisasi. Dalam organisasi yang menerapkan manajemen kualitas, visi ini akan mencakup suatu transformasi dari organisasi menuju komitmen total terhadap perbaikan kualitas terus menerus.

2. Memiliki peta untuk tindakan. Pemimpin transformasional mengetahui bagaimana menerjemahkan visi sekolah ke dalam kenyataan. Mereka dapat secara efektif merencanakan bagaimana mencapai visi yang telah disepakati bersama oleh seluruh anggota organisasi itu.

3. Memiliki kerangka untuk visi (frame for the vision). Pemimpin transformasional dapat menyusun visi ke dalam suatu kerangka kerja yang jelas, yang secara akurat menggabungkan visi itu dengan nilai-nilai yang telah diyakini oleh seluruh anggota organisasi itu.

4. Memiliki kepercayaan diri. Pemimpin transformasional memiliki kepercayaan yang tinggi serta selalu bersikap optimis dan tidak kehilangan akal dalam menghadapi suatu masalah.

5. Berani mengambil risiko. Pemimpin transformasional berani mengambil resiko dalam merealisasikan visi mereka yang telah ditansformasikan menjadi visi bersama dari seluruh anggota dalam suatu sekolah. Pemimpin transformasional menginginkan perubahan-perubahan pendekatan berupa ide- 
ide baru, praktek-praktek baru, atau cara-cara baru dalam memecahkan masalah-masalah kualitas.

6. Memiliki gaya pribadi inspirasional. Pemimpin transformasional memiliki daya magnetis pribadi yang kuat sehingga membuat pengikut-pengikutnya merasa dekat dengan pemimpinnya. Dengan demikian, pemimpin transformasional dapat memotivasi pengikut-pengikutnya menuju peningkatan performansi yang lebih baik.

7. Memiliki kemampuan merangsang usaha-usaha individual. Pemimpin transformasional memiliki kemampuan mengidentifikasi potensi yang ada dari setiap individu dalam organisasi, yang kemudian merangsang dan membantu si individu itu secara intelektual agar berkembang untuk mancapai visi organisasi yang telah disepakati bersama.

8. Memiliki kemampuan mengidentifikasi manfaat-manfaat. Pemimpin transformasional memiliki kemampuan mengidentifikasi manfaat-manfaat yang diperoleh apabila mengikuti visi sekolah yang telah disepakati bersama itu. Pemimpin transformasional dapat secara langsung menunjukkan penghargaan dan pengakuan atas keberhasilan apabila mencapai visi organisasi yang telah disepakati bersama itu.

Pendidikan Islam tidak hanya dapat dilakukan di suatu lembaga pendidikan (pendidikan formal), namun dapat juga di lakukan di rumah (pendidikan informal) maupun dilingkungan masyarakat (pendidikan non formal). Pendidikan informal misalnya yang mana kita ketahui bahwa pendidikan yang pertama kali kita dapatkan adalah di dalam sebuah keluarga. Sedangkan untuk pendidikan non formal (kemasyarakatan) dapat di lihat dari bentuk yang sederhana sampai yang sudah modern, seperti masjid, musola, majelis ta'lim, TK/TPA, Islamic center, dan lain-lain.

Dan untuk pendidikan formal, secara struktural di lihat dari segi program serta praktek pendidikan Islam di Indonesia yang ada, seperti: pendidikan pondok pesantren, madrasah, dan pendidikan umum yang bernafaskan Islam. Dari beragam jenis pendidikan Islam yang ada, penulis mengetengahkan madrasah sebagai fokus kajian terhadap penelitian yang dilakukan, mengingat keterbatasan yang ada.

Pendidikan yang berkualitas sering diidentikkan dengan pendidikan yang "elit", "mahal", dan "prestisius", padahal tidaklah demikian, oleh karena untuk 
mencapai pendidikan berkualitas diperlukan adanya komponen yang sesuai dengan standar kebutuhan bagi penyelenggaraan pendidikan bermutu.

Kualitas pendidikan sebagai pilar pengembangan sumber daya manusia, erat hubungannya dengan manajemen pada lembaga pendidikan. Pendidikan yang berkualitas akan muncul apabila sekolah berkualitas, yang tidak terlepas dari pengelolaan secara benar. Kualitas pendidikan tidak terlepas atas inputs, proses, outputs maupun outcomes. Oleh sebab itu, pendidikan harus terus menerus di tingkatkan kualitasnya melalui suatu sistem manajemen yang dapat di pertanggung jawabkan kepada para stakeholder agar mampu mempersiapkan generasi penerus yang memiliki keunggulan kompetitif dalam menjawab dan memecahkan tantangan masa depan bangsa di era global.

Untuk dapat menyongsong tantangan globalisasi yang akan datang, dunia pendidikan harus mengubah diri di mulai dengan mengubah pola pikir pokok (mindset) dalam mengelola dan menyelenggarakan pendidikan. Wardiman Djojonegoro menyatakan pola pikir ini bertolak pada:

1. Sekolah bukanlah tujuan akhir, tetapi adalah tempat mendapatkan bekal untuk meneruskan profesi/ pekerjaan.

2. Siswa merupakan titipan masyarakat kepada dunia pendidikan

3. Pengabdian para pendidik tercapai jika anak didik kita di terima dan berkarya di dunia luar (dunia kerja) dan berhasil maju.

4. Dunia luar berubah terus, sehingga ilmu yang di ajarkan juga harus di sesuaikan terus - menerus, karenanya dunia pendidikan harus pula selalu berhubungan dengan dunia luar untuk dapat mengetahui perubahan tersebut.

5. Kompetensi atau kapabilitas siswa menjadi ukuran utama, sehingga kurikulum di tentukan bersama dengan dunia luar/ pasar, berdasarkan kebutuhan saat ini dan dimasa depan.

6. Penyelenggaraan pendidikan harus luwes, dalam arti bahwa ilmu dan pengetahuan dapat di pelajari secara bertahap dan dimana saja.

7. Karena ragamnya setiap daerah di Indonesia; khususnya dalam perkembangan ekonomi, maka perlu ada keluwesan dalam penyelenggaraannya. Prinsip ini mengisyaratkan adanya suatu desentralisasi kewenangan pendidikan kepada wilayah.

8. Pembiayaan pendidikan yang masih jauh dari ideal menuntut agar sekolah di beri kemandirian untuk mencari keuangannya sendiri. (Ing.Wardiman Djojonegoro,2002 : 271-272). 
Upaya peningkatan kualitas pengelolaan pendidikan berkaitan langsung dengan kualitas: sumber daya manusia, sumber daya fasilitas, proses, layanan, kepemimpinan, yang berpengaruh pada outputs dan outcomes. Asumsi ini menunjukkan peran manajemen dalam pendidikan cukup signifikan. Dan dalam implementasinya membutuhkan upaya inovasi dan improvisasi guna meningkatkan kualitas pendidikan secara terus menerus. Perbaikan manajemen pendidikan diarahkan untuk lebih memberdayakan sekolah sebagai unit pelaksanaan terdepan dalam kegiatan belajar mengajar di sekolah.

Perbaikan manajemen pendidikan sebaiknya diarahkan kepada pemberdayaan sekolah sebagai unit pelaksanaan yang di dalamnya terdapat proses belajar mengajar. Ini dimaksudkan agar sekolah lebih mandiri dan bersikap kreatif, sehingga dapat mengembangkan iklim kompetitif antar sekolah di wilayahnya, serta bertanggung jawab terhadap stakeholder pendidikan, khususnya orang tua dan masyarakat (Sidi, 2001: 19). Dengan demikian manajemen pendidikan harus lebih terbuka, sehingga dapat mempertanggung jawabkan semua program kegiatannya., serta mengoptimalkan partisipasi orang tua dan masyarakat serta dapat mengelola semua sumber daya yang tersedia di sekolah dan lingkungannya untuk digunakan seluas-luasnya bagi penigkatan prestasi siswa dan mutu pendidikan pada umumnya. Dengan demikian perlu dikembangkan sebuah strategi untuk mengantarkan pendidikan kita menuju masa depan yang lebih baik, lebih berkualitas, dan lebih fungsional, baik dari lembaga pendidikan itu sendiri maupun bagi masyarakat, bangsa dan negara secara keseluruhan.

Madrasah dalam hal ini sebagai lembaga pendidikan Islam yang berfungsi untuk meningkatkan kualitas sumber daya manusia menjadi tumpuan harapan masyarakat muslim untuk kepentingan pendidikan putra-putri mereka. Untuk memenuhi kebutuhan ini tentu madrasah membutuhkan konsep manajemen yang baik sehingga dapat melakukan inovasi dan improvisasi dalam memenuhi kebutuhan masyarakat muslim dalam menghadapi perkembangan global yang semakin kompetitif. Namun sangat disayangkan, sampai saat ini madrasah jika dibandingkan dengan pendidikan umum lainnya masih tertinggal, khususnya 
dalam hal persaingan kualitas outputs. Meskipun usaha perbaikan telah dilakukan dengan memperbaiki kurikulum dan memberi mata pelajaran umum $70 \%$ dan $30 \%$ sisanya pelajaran agama (Rahim, $2001: 138)$.

Fenomena madrasah yang masih di anggap sebagai lembaga pendidikan kedua, yang seringkali keberadaannya di anggap hanya sebagai sekolah cadangan. Apalagi hampir semua madrasah dalam upaya pengembangannya, masih tergolong miskin sumber daya, di tambah pula dengan sistem pengelolaan yang kurang profesional, membuat madarasah kurang bermutu dan outputsnya tidak dapat bersaing dengan alumni dari sekolah umum lainnya. Ini dapat kita lihat dari rendahnya nilai UAN/UAS dan kurang berpeluangnya alumni madrasah dalam merebut peluang kerja dan menduduki kursi perguruan tinggi bergengsi.

Madrasah mampu meningkatkan mutu pendidikannya apabila setiap komponen yang ada di madrasah mampu bekerja secara kompak demi peningkatan prestasi peserta didik. Menyikapi persoalan mutu pendidikan, dalam hal ini pendidikan Islam yang diselenggarakan di madrasah pada umumnya terbentur pada kualitas sumber daya manusia. Yang mana persoalan ini masih menjadi problema dalam dunia pendidikan Islam, di tambah dengan lemahnya kreativitas kepala sekolah serta lambannya informasi di tingkat lokal/sekolah.

Menurut PP No.28/1990 dan di pertegas oleh keputusan Menteri Pendidikan Nasional RI Nomor 053/U/2001 tentang Pedoman Penyusunan Standar Pelayanan Minimal Penyelenggaraan Persekolahan Bidang Pendidikan Dasar dan Menengah bahwa penilaian keberhasilan pendidikan di sekolah mencakup empat komponen sebagai berikutRochaety, 2005: 126).

1. Komponen pertama yang di ukur adalah kegiatan dan kemajuan belajar siswa. Tujuannya terutama untuk mengetahui bagaimana proses pembelajaran berlangsung, proses pembimbingan dan pembinaan kepada siswa, mengukur efektivitas dan efisiensi penyelenggaraan perkembangan hasil belajar siswa.

2. Komponen kedua berkenaan dengan pelaksanaan kurikulum. Tujuannya untuk mengetahui kesesuaian kurikulum dengan dinamika tuntutan kebutuhan masyarakat, pencapaian kemampuan siswa berdasarkan standar kompetensi yang telah di tetapkan, ketersediaan sumber belajar yang relevan 
dengan tuntutanan kurikulum, cakupan materi muatan lokal sesuai dengan kebutuhan daerah setempat, serta kelancaran pelaksanaan kurikulum sekolah secara keseluruhan.

3. Komponen ketiga adalah guru dan tenaga kependidikan lainnya. Di maksudkan untuk mengetahui sampai seberapa jauh kemampuan dan kewenangan profesional masing-masing personel dapat di tampilkan dalam pekerjaan sehari-hari.

4. Komponen keempat, kinerja satuan pendidikan sebagai satu keseluruhan. Penilaiannya mencakup kelembagaan, kurikulum, siswa, guru, dan non guru, sarana/prasarana, administrasi, serta keadaan umum satuan pendidikan tersebut.

Penilaian ini dilakukan untuk melihat sejauh mana mutu pendidikan yang bisa di capai sekolah tersebut, dan bagaimana posisinya jika dibandingkan dengan sekolah yang ada di sekitarnya maupun di tingkat nasional. Jadi tujuan dari penilaian ini yaitu sebagai alat kontrol bagi perbaikan dan pengembangan mutu sekolah selanjutnya. Banyak hal yang dapat dilakukan untuk meningkatkan mutu pendidikan khususnya pada madrasah. Salah satu upaya dalam meningkatkan mutu pendidikan adalah dengan menerapkan dari prinsip-prinsip yang ada pada TQM, yang mana prinsip utama dari TQM ini adalah mementingkan kepuasan pelanggan, dalam hal ini pelanggan pendidikan. Dalam konteks TQM, kualitas bukan hanya merupakan suatu inisiatif, melainkan suatu filosofi dan metodologi yang membantu lembaga untuk mengelola perubahan secara totalitas dan sistemik sehingga terjadi perubahan paradigma, visi, misi, dan juga tujuan (Suderadjat, $2004: 142)$.

Kemampuan manajemen yang baik dalam pendidikan Islam mendukung terlaksananya pendidikan yang baik. Hal ini sangat beralasan karena dengan proses keteraturan dalam manajemen akan mampu mengendalikan segala bentuk perubahan yang ditimbulkan. Konsep TQM bertumpu pada kualitas pengelolaan SDM yang ada di sekolah. Apabila sumber daya manusianya siap maka dengan cepat perubahan yang ada di sekolah akan cepat pula ataupun sebaliknya. Dalam rangka peningkatan mutu sekolah, maka di bawah ini yang di kutip dari Sallis Edward mengenai perbedaan antara sekolah yang berkualitas dan sekolah yang konvensional. 
Tabel 1.

Perbedaan antara sekolah yang berkualitas dan sekolah yang konvensional

\begin{tabular}{|c|c|c|}
\hline No. & Sekolah Berkualitas & Sekolah Konvensional \\
\hline 1 & Berfokus Pelanggan & Berfokus pada kebutuhan internal \\
\hline 2 & $\begin{array}{l}\text { Berfokus pada pencegahan } \\
\text { masalah }\end{array}$ & $\begin{array}{l}\text { Berfokus pada pemecahan masalah } \\
\text { yang terdektesi }\end{array}$ \\
\hline 3 & $\begin{array}{l}\text { Investasi dalam staf (staf yang } \\
\text { profesional) }\end{array}$ & Penataran staf yang tidak sistematik \\
\hline 4 & $\begin{array}{l}\text { Ada strategi peningkatan } \\
\text { kualitas }\end{array}$ & tidak ada \\
\hline 5 & $\begin{array}{l}\text { Memperlakukan hambatan dan } \\
\text { kekuarangan sebagai } \\
\text { kesempatan untuk belajar }\end{array}$ & $\begin{array}{l}\text { Kekurangan dan kelemahan di anggap } \\
\text { sebagai gangguan }\end{array}$ \\
\hline 6 & $\begin{array}{l}\text { Telah menetapkan karakteristik } \\
\text { kualitas untuk semua bagian }\end{array}$ & Standar kualitas masih samar \\
\hline 7 & $\begin{array}{l}\text { Telah memiliki rencana dan } \\
\text { kebijakan dalam kualitas }\end{array}$ & Tidak ada \\
\hline 8 & $\begin{array}{l}\text { Manajer senior lebih profeisonal } \\
\text { dari staf }\end{array}$ & $\begin{array}{l}\text { Peranan manajemen terlihat sebagai } \\
\text { suatu pengawasan }\end{array}$ \\
\hline 9 & $\begin{array}{l}\text { Proses peningkatan } \\
\text { melibatkan semua orang }\end{array}$ & $\begin{array}{l}\text { Hanya melibatkan kelompok } \\
\text { manajemen }\end{array}$ \\
\hline 10 & $\begin{array}{l}\text { Fasilitator kualitas membimbing } \\
\text { proses peningkatan }\end{array}$ & Tidak ada fasilitator kualitas \\
\hline 11 & $\begin{array}{l}\text { Orang dalam organisasi terlihat } \\
\text { menciptakan kualitas. Kualitas } \\
\text { di galakkan }\end{array}$ & $\begin{array}{l}\text { Yang di pentingkan adalah prosedur } \\
\text { dan peralatan }\end{array}$ \\
\hline 12 & $\begin{array}{l}\text { Ada kejelasan dalam aturan dan } \\
\text { tanggung jawab }\end{array}$ & Kabur \\
\hline 13 & Ada kejelasan strategi evaluasi & $\begin{array}{l}\text { Tidak ada strategi evaluasi yang } \\
\text { sistematik }\end{array}$ \\
\hline 14 & $\begin{array}{l}\text { Memandang kualitas sebagai } \\
\text { sarana untuk meningkatkan } \\
\text { kepuasan pelanggan }\end{array}$ & $\begin{array}{l}\text { Memandang kualitas sebagai sarana } \\
\text { untuk mengurangi biaya }\end{array}$ \\
\hline 15 & Rencana jangka panjang & Jangka pendek \\
\hline 16 & $\begin{array}{l}\text { Kualitas di pandang sebagai } \\
\text { bagian dari budaya }\end{array}$ & $\begin{array}{l}\text { Kualitas di pandang sebagai inisiatif } \\
\text { lain yang mengganggu }\end{array}$ \\
\hline 17 & $\begin{array}{l}\text { Pengembangan kualitas sejalan } \\
\text { dengan lembaga }\end{array}$ & $\begin{array}{l}\text { Kualitas di ujikan untuk memenuhi } \\
\text { harapan lembaga eksternal }\end{array}$ \\
\hline 18 & $\begin{array}{l}\text { Memiliki visi, misi, dan tujuan } \\
\text { yang baik }\end{array}$ & Tidak \\
\hline 19 & $\begin{array}{l}\text { Memperlakukan guru dan staf } \\
\text { sebagai pelanggan }\end{array}$ & $\begin{array}{l}\text { Memperlakukan staf dan guru sebagai } \\
\text { bawahan. }\end{array}$ \\
\hline
\end{tabular}

Sumber : Edward Sallis, Total Quality Management, London: Kogan Page,Ltd, 1993 
Mutu pendidikan merupakan sesuatu persoalan yang menjadi target pada setiap program pendidikan. Mutu pendidikan umumnya diartikan sebagai gambaran seberapa jauh lembaga pendidikan berhasil mengubah tingkah laku peserta didik, dan bila dikaitkan dengan tujuan pendidikan mutu pendidikan juga disebut kualitas yang artinya gambaran sifat suatu hal yakni tingkat baik buruknya suatu hal. Untuk itu perlu adanya suatu inovasi dalam pengembangan manajemen yang harus menuntut adanya perubahan paradigma, orientasi, pendekatan cara berfikir, serta bersikap kreatif terhadap permasalahan pendidikan yang di hadapi, agar upaya peningkatan mutu pendidikan dapat dilakukan dengan penuh tanggung jawab. Kepala sekolah dalam menjalankan kepemimpinan pendidikan, perlu melakukan beberapa hal penting, sebagaimana dikemukakan oleh Sallis. Usahausaha itu diantaranya:

1. Melibatkan guru-guru dan semua staf dalam aktivitas penyelesaian masalah dengan menggunakan metode ilmiah, dan prinsip proses pengawasan mutu dengan statistik,

2. Mintalah pendapat dan aspirasi mereka tentang sesuatu dan bagaimana sebuah proyek ditangani, karena itu jangan menggurui mereka,

3. Pahamilah bahwa keinginan untuk perbaikan yang berarti bagi guru-guru tidak cocok dengan pendekatan atas bawah (top down) terhadap manajemen,

4. Pelaksanaan yang sistematik dan komunikasi yang terus menerus dengan melibatkan setiap orang disekolah

5. Bangunlah keterampilan-keterampilan dalam mengatasi konflik penyelesaian masalah dan negosiasi

6. Berikanlah pendidikan dalam konsep mutu dan pelajaran seperti membangun tim kerja, proses manajemen, pelayanan pelanggan, komunikasi dan kepemimpinan

7. Berikanlah otonomi dan keberanian mengambil resiko dari para guru atau staf.

Upaya perbaikan kualitas secara berkesinambungan dalam lembaga pendidikan harus menggunakan pendekatan sistem terbuka atas fungsi inti lembaga pendidikan, student learning. Ada tiga pendekatan yang digunakan untuk menjamin kualitas lembaga pendidikan, yaitu (1) pendekatan akreditasi, (2) pendekatan outcomes assessment, dan (3) pendekatan sistem terbuka (Rochaety,dkk., 2005: 121). Hal ini telah dilakukan di MTs Negeri 2 
Palembang.Penyempurnaan kualitas berkesinambungan dalam lembaga pendidikan dapat diilustrasikan dalam gambar berikut ini : 
Gambar I.2.

Penyempurnaan kualitas berkesinambungan dalam lembaga pendidikan

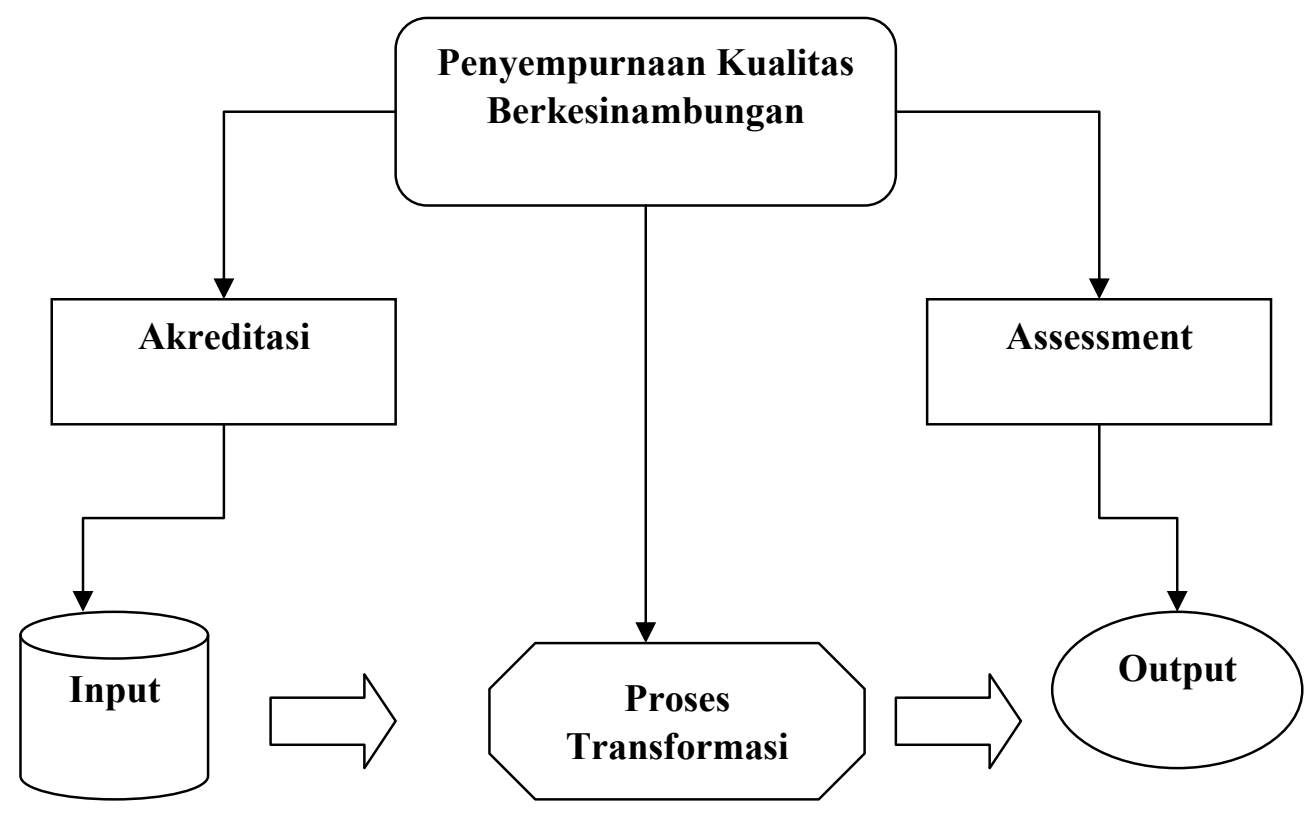

-Karakteristik Siswa

-Karakteristik Kelas

-SumberDaya

Finansial

-Fasilitas

-Program
-Desain

-Input Program

-Metode

Penyampaian

Sistem Data

-Umpan Balik

-Analisis
-Prestasi Siswa

-Siswa

lulus/drop-

out/gagal

-Alumni

berprestasi

Sumber: Eti Rochaety,dkk. Sistem Informasi Manajemen Pendidikan, Bumi Aksara, Jakarta, 2005.

Pendekatan akreditasi berfokus pada inputs lembaga pendidikan, seperti prestasi siswa, jumlah kelas, dan sumber daya fisik. Jika pendekatan ini tersedia input berkualitas tinggi, akan di peroleh hasil output berkualitas tinggi pula. Pendekatan outcomesassessment menekankan pentingnya evaluasi lulusan lembaga pendidikan, seperti prestasi siswa, graduation, dan pekerjaan/ jabatan yang di peroleh. Dalam pendekatan ini memberikan masukan yang berharga bagi lembaga pendidikan, siswa, dan masyarakat, pemahaman atas outputs pendidikan hanya semata-mata proses pembelajaran. 
Pendekatan akreditasi maupun outcomes assessment, keduanya belumlah lengkap dalam upaya menjamin kualitas lembaga pendidikan. Untuk itu, dibutuhkan pendekatan sistem terbuka yang menekankan kebutuhan akan kualitas pada tiga tahap utama, yaitu inputs, proses transformasi, dan outputs. Upaya penyempurnaan kualitas harus difokuskan pada ketiga tahap tersebut dengan mempertimbangkan tantangan atas perlunya pemenuhan standar kualitas lembaga pendidikan.

\section{Kesimpulan}

Berdasar pada pemaparan di atas, adapun simpulan penelitian ini adalah strategi Manajemen kualitas yang ada di Madrasah Ibtitaiyah Negeri 2 Palembang yaitu dengan input yang sudah dilakukan penyaringan, proses belajar mengajar berjalan dengan baik meskipun sarana prasarana sangat standar MTs pada umumnya dan dari segi output dapat diterima di sekolah umum dan agama negeri. Prinsip perbaikan dari TQM, yakni dengan dilakukannya peningkatan kualitas dalam semua sektor dan dilakukan oleh semua orang dalam sekolah serta dilakukan secara terus menerus termasuk di MTs Negeri 2 Palembang. Diharapkan semua madrasah memiliki prinsip ini, karena dengan berobsesi pada kualitas maka apa yang diinginkan atau dicapai tidaklah pernah cukup (good enough is never good enough), perlu diingat bahwa kualitas merupakan kondisi yang selalu berubah (misalnya apa yang dianggap berkualitas saat ini mungkin dianggap kurang berkualitas pada masa mendatang). Dengan demikian madrasah harus terus berupaya untuk menjadikan madrasahnya menjadi madrasah yang berkualitas. 


\section{Daftar Pustaka}

Azra, A. (2000).“Desentralisasi Pendidikan dan Otonomi Daerah: Implikasinya terhadap pendidikan Islam”,Jurnal Komunikasi Dunia Perguruan Madrasah Vol.4 No.1,Jakarta : Pusat Pengkajian Islam dan Masyarakat (PPIM).

Danim, S. (2002).Inovasi Pendidikan dalam upaya peningkatan profesionalisme Tenaga Kependidikan. Bandung: Pustaka Setia.

Danim, S. (2006). Visi Baru Manajemen Sekolah dari Unit Birokrasi ke Lembaga Akademik.Jakarta: Bumi Aksara.

Depdiknas. (2001). Manajemen Peningkatan Mutu Berbasis Sekolah, Jakarta: Direktorat Jenderal Pendidikan Dasar dan Menengah.

Djojonegoro, Ing.W. (2002). Pendidikan untuk Indonesia Baru 70 Tahun Prof. DR.H.A.R.Tilaar.Jakarta: Grasindo.

Gasperz, V. (2001).Total Quality Management. Jakarta: Gramedia Pustaka Utama.

Komariah, A.\& Triatna, C. (2005).Visionary Leadership Menuju Sekolah Efektif. Jakarta: Bumi Aksara.

Nurkolis. (2003). Manajemen berbasis sekolah Teori, Model, dan Aplikasi. Jakarta :Grasindo.

Rahim, H. (2001). Arah Baru Pendidikan Islam di Indonesia.Jakarta: Logos.

Rochaety, E. dkk. (2005).Sistem Informasi Manajemen Pendidikan. Jakarta: Bumi Aksara.

Sagala,S.(2004). Manajemen Berbasis Sekolah \& Masyarakat Strategi Memenangkan Persaingan Mutu. Jakarta: Nimas Multima.

Sidi, I. D. (2001). Menuju Masyarakat Belajar Menggagas Paradigma Baru Pendidikan.Jakarta: Logos.

Suderadjat, H. (2004).Implementasi KBK, Pembaharuan Pendidikan dalam UU SISDIKNAS 2003, Cet.1. Bandung: Grafika.

Tunggal, A. W. (1998).Manajemen Mutu Terpadu Suatu Pengantar, Cet.2. Jakarta: Rineka Cipta. 